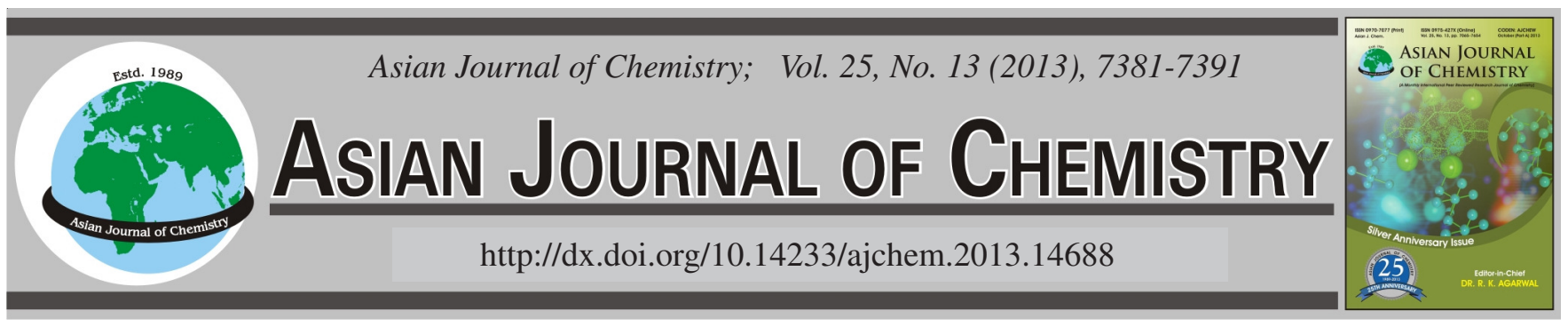

\title{
Assessment of Spatial Variation and Chemical Properties of Groundwater Near Municipal Solid Waste Landfill in Mashhad, Iran
}

\author{
Elmira Shamshiry ${ }^{1, *}$, Mazlin Bin Mokhtar ${ }^{1}$, Ibrahim Komoo ${ }^{2}$, Halimaton SaAdiah Hashim ${ }^{1}$, \\ Nadzri Yahya ${ }^{3}$, Behzad Nadi ${ }^{2}$, Abdul-Mumin Abdulai $^{4}$ and Dariush Talei ${ }^{5}$
}

\begin{abstract}
${ }^{1}$ Institute for Environment and Development (LESTARI), Universiti Kebangsaan Malaysia, 43600 Bangi, Selangor, Malaysia ${ }^{2}$ Southeast Asia Disaster Prevention Research Institute, University Kebangsaan Malaysia, 43600 Bangi, Selangor, Malaysia ${ }^{3}$ National Solid Waste Management Department, Ministry of Housing and Local Government, 62100 Putrajaya, Malaysia ${ }^{4}$ Kulliyyah of Islamic Revealed Knowledge and Human Sciences, International Islamic University, P.O. Box 10, 50728 Kuala Lumpur, Malaysia ${ }^{5}$ Medicinal Plant Research Center, Shahed University, Tehran, Iran

*Corresponding author: E-mail: ele_shame19@yahoo.com
\end{abstract}

\section{INTRODUCTION}

Solid waste management is a widely discussed topic, including in developing countries that depend substantially on tourism as one of the main sources of income. In that context, this research investigates components of an integrated solid waste management approach in Mashhad (Iran), in their pursuit towards sustainable regional development that this research is focus on collection and transportation of solid waste as part of integrated solid waste management approach with environmental and economical issues to protect the Mashhad city as the second largest city for pilgrim (after Mecca) in the world and special situation because of high amount of population and industrial axis (after Tehran) in Iran. Leachate can pollute the groundwater if not collected and treated ${ }^{1}$. Selection of the most appropriate method depends on local conditions. Methods for solid waste sanitary landfill differ according to geographical situation, level of ground water and amount of available soil for solid waste covering.
Most of the landfills in developing countries don't have machinery to collect leachate and monitoring systems. No monitoring is implemented in uncontrolled landfills and there is no survey on the risks of environmental and human health. The surface and ground water, soil, plants in area and air receive pollution from landfill leachate ${ }^{2,3}$. Leachate organized a flow that is highly aggressive and dangerous to the environment, with a pollution exceeding that of several industrialwaste materials ${ }^{4}$. Johnbosco and Nnaji ${ }^{5}$ studied about landuse plan impact in Otmiri river to verify the environmental quality. Samples were taken from places nearest to landfill. The final results showed the values of some variables were over-passed the limitations of WHO standards. Olorunfemi et al. ${ }^{6}$ tested bio-monitoring of raw leachate from some urban waste dump sites, raw leachate was taken from three open dump sites.

The final results compare with the control. The physical and chemical characteristics demonstrated that the leachates were acidic and included toxic chemicals, presented in those 
leachates were a threat for the environment and resident health in area without checked them. Emmanuel et $a l^{7}$ studied the effects of pollution by bacteria in dump site. Sufficient treatment for dump site recommended decreasing health hazards. Ezekiel et al. ${ }^{8}$ searched the physical and chemical condition of Sombreiro river in Nigeria for a period of two years. The temperature value in river reported was normal, the salinity, biochemical oxygen and dissolved oxygen had clear sign of fresh water in the upper and middle of river. The mean biochemical oxygen demand value was showed that the water is not polluted. Charkhabi and Sakizadeh ${ }^{9}$ studied water parameters in 9 stations in all 4 continuous season on the Siahroud river. The result showed that total dissolved solid value in some parts is high. Amount of ammonium in downstream of site is high. Imoobe and Koye ${ }^{10}$ investigated impact of discharge of industrial plant on Eruvbi stream, water sample taken from 3 sample points were analyze after that parameters compared with limitation of federal environmental protection agency, amount of turbidity was more than allowable measure, amount of oxygen were the lower than minimum limits. Many elements effect on the compound of leachate such as types of waste, waste composition, the climatic condition and landfill age ${ }^{11,12}$. Kumar and Alappat ${ }^{13}$ described leachate pollution index as a tool for quantifying pollution of landfill leachate in Hong Kong. Rezai et al. ${ }^{14}$ evaluated chemical pollution of groundwater (downstream) of landfill in Sanandaj, Iran. Five wells near to landfill were chosen, after six stages sampling monthly several parameters was measured. The results were compared with drinking and agricultural water standards. The result demonstrated the well's water were not suitable for drinking because amount of measured chemical parameters is high. Kumar and Allapat ${ }^{13}$ analyzed leachate pollution and formulized sub leachate contamination indices, the characteristics of UK's leachate is studied. The results showed that the organic parameter is more than the inorganic and heavy metals amount that can be beneficial for experts in decision making and management issues for treatment of leachate.

Produced leachates from landfill contain a number of contaminations and may have an environmental effect on the soil and surface water in area, Leachate may be very contaminated; therefore it has a risk to human health. Therefore, leachate management become a crucial issue in decision making process and needs strategy for development planning.

Kassenga and Mbuligwe ${ }^{15}$ stated the effects of solid waste disposal site on qualification of soil, river sediments, surface and groundwater in Tanzania. Sampling implemented in wet and dry season and physical, chemical and parameters such as $\mathrm{Pb}, \mathrm{Cd}, \mathrm{Cr}$ and $\mathrm{Zn}$. The disposal site had found to be a P value significant $(\mathrm{p}<0.05)$ contamination source to soil, ground and surface water in near that area. Effects of season also explained in research. Charles and Okoro ${ }^{16}$ investigated heavy metals and physico-chemical leachate characteristics of the various sites from dump site in Obehe and Ubakala, Port Harcourt. The test were related to $\mathrm{pH}$, TDS, electric conductivity, COD, DO and elements of Fe, $\mathrm{Zn}, \mathrm{Cu}, \mathrm{Mn}, \mathrm{Cr}$, $\mathrm{As}, \mathrm{Cd}, \mathrm{Pb}$. The results were found physico-chemical leachates characteristics to high and some acidic condition. Tay et al. ${ }^{17}$ determined trace metal level in water and sediment from the
Sakumo II and Muni lagoons and the Mamahuma and Gbagbla Ankonu feeder streams during one year. Moreover, temperature, $\mathrm{pH}$ and electrical conductivity of physical parameters had checked. The final results were described as potential sources of trace metal pollution to the Sakumo II lagoon and the Sakumo II lagoon could be explained more contaminated by trace load of metal.

\section{EXPERIMENTAL}

Study area: Mashhad is a provincial center in Khorasan Razavi and second metropolis in Iran. Mashhad is located at $36.20^{\circ}$ latitude north and $59.35^{\circ}$ longitude east, in the valley of the Kashaf river near Turkmenistan, between the two mountain ranges of Binalood and Hezar-masjed. The city benefits from the proximity of the mountains, having cool winters, pleasant springs, mild summers and beautiful autumns. It is divided into 4 districts, 14 villages and 660 hamlets and is considered as one of the biggest cities in Khorasan Razavi state.

In terms of its population, Mashhad has a population of nearly 3 million (2009) and an area of 29,000 hectares and it is also known for its industrial and agricultural productions. In addition, it is one of the largest religious cities in the world. According to Mashhad statistic center, more than 20 million tourists and pilgrims visit this city.

Investigating leachate of landfill and solid waste disposal in general seeking to improve environmental quality can boost the image of Mashhad, Iran towns as tourism destinations and the personal health of their residents. Significance of this research is that Mashhad is a tourism hub in Iran.

Methods: In order to scrutinize the quality of ground water supplies downstream of the Mashhad landfill, from seven wells available downstream of the current landfill solid waste site of Mashhad city, sampling was done from January 2010 to January 2011 (that is, sampling twice per week) at 8 am to 12 noon and all the samples were kept at a temperature of $4{ }^{\circ} \mathrm{C}$ (bacterial growth was low in this temperature). It is necessary to mention that because of limitation of facilities related to the test, selected elements have been measured in this study.

Due to the absence of surface water in the area during sampling, sampling was limited to regional groundwater. Seven samples of groundwater were collected. For sampling $250 \mathrm{~mm}$ polyethylene bottles with double caps were used. In the process of sampling the bottles were rinsed at least three times with the sample water. Steps were taken to ensure that the bottles were completely full to eliminate any air bubbles in the samples.

Acidity and electrical conductivity, temperature and sulphur hydrogen gases and carbon dioxide dissolved in water are measured in sampling site and how to measure these parameters is briefly explained. Amount of electrical conductivity (EC) for all water samples in sampling site ${ }^{18}$ with EC meter machine made by $\mathrm{HACH}$. This measurement was done January 2010 - January 2011 during the four seasons in Iran. Accuracy of this machine for measuring electrical conductivity is equal to $1 \mu \mathrm{mhos} / \mathrm{cm}$. Within less than $2000 \mu \mathrm{mhos}$ and within more than $2000 \mu \mathrm{mhos}$ is equal to $10 \mu \mathrm{mhos} / \mathrm{cm}$. Amount of acidity or $\mathrm{pH}$ for all water samples and electrical 
SOME RESULTS OF AVERAGE SELECTED PARAMETERS OF GROUND WATER SAMPLES IN MASHHAD JANUARY 2010 TO JANUARY 2011 (TWICE PER WEEK) BETWEEN 8 AM-12 NOON

\begin{tabular}{|c|c|c|c|c|c|c|c|}
\hline Station & Coordinates & $\mathrm{EC}(\mu \mathrm{S} / \mathrm{cm})$ & $\mathrm{pH}$ & Temp. $\left({ }^{\circ} \mathrm{C}\right)$ & $\mathrm{CO}_{2}(\mathrm{mg} / \mathrm{L})$ & $\mathrm{H}_{2} \mathrm{~S}(\mathrm{mg} / \mathrm{L})$ & $\begin{array}{l}\text { Distance from } \\
\text { landfill site }(\mathrm{m})\end{array}$ \\
\hline 1 & $59^{\circ} 39 / 55^{\prime \prime} *, 36^{\circ} 10 / 53^{\prime \prime} * *$ & 505 & 8.18 & 21 & 0.9 & 2.4 & 2500 \\
\hline 2 & $59^{\circ} 40 / 54^{\prime},, 36^{\circ} 10 / 40^{\prime \prime}$ & 694 & 8.22 & 20.8 & 0.4 & 1.2 & 3700 \\
\hline 3 & $59^{\circ} 41 / 57^{\prime}, 36^{\circ} 10 / 11^{\prime}$, & 919 & 8.25 & $25 / 2$ & 0.1 & 1.4 & 5450 \\
\hline 4 & $59^{\circ} 43 / 2^{\prime}, 36^{\circ} 10 / 41^{\prime \prime}$ & 780 & 8.32 & 21.7 & 3.1 & 1.5 & 6500 \\
\hline 5 & $59^{\circ} 42 / 10^{\prime}, 36^{\circ} 12 / 1^{\prime}$, & 811 & 7.7 & 21.8 & 3.2 & 1.5 & 6000 \\
\hline 6 & $59^{\circ} 38 / 38^{\prime},, 36^{\circ} 17 / 6^{\prime}$, & 1585 & 7.19 & 19.8 & 5.2 & 16.2 & - \\
\hline
\end{tabular}

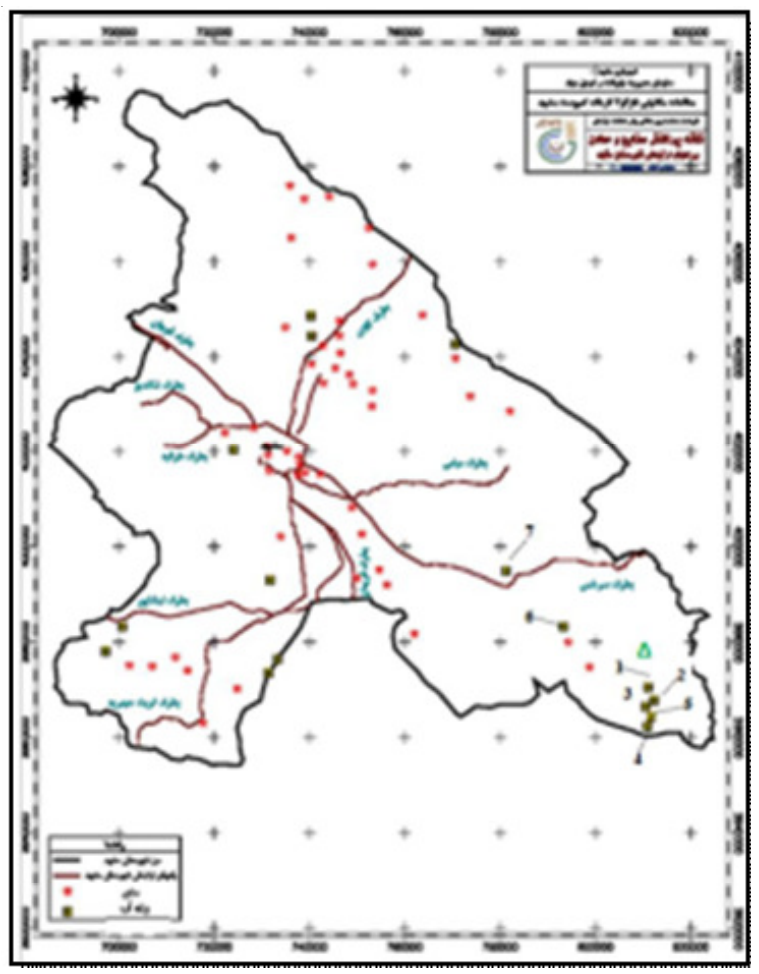

Fig. 1. Map of Mashhad that clarify place of landfill $\Delta$ and wells number 1, 2, 3, 4, 5, 6 and 7, Source: Mashhad Municipality 2010

conductivity was done at the sampling site; using model $\mathrm{pH}$ meter machine $\mathrm{HACH}$. This system's accuracy is equal to unit 0.1 for $\mathrm{pH}$ measurement ${ }^{19}$. Temperatures for all samples in sample sites were done with thermometer ${ }^{20}$ and the two above parameters (electrical conductivity and acidity) simultaneously. This measurement with thermometer equipped EC meter was done at the water sampling site. Temperature measuring accuracy by this system was $0.1^{\circ} \mathrm{C}$ based on Iranian Standard Institute (Institute of Standards and Industrial Research of Iran (ISRI)). To measure this parameter, $100 \mathrm{~mL}$ of pure water sample in $200 \mathrm{~mL}$ beaker was added with 5-6 drops of phenolphthalein solution and swirl the flask to mix and then determine this by carefully adding drops of $0.02 \mathrm{~N} \mathrm{NaOH}$, one at a time, swirling the water after each drop to ensure a complete reaction. Counting the number of drops of $\mathrm{NaOH}$ that is added. This action was continued until the water colour changed from colourless to light pink. A reading of the amount of sodium hydroxide used is taken at the moment the water changed colour. A relationship was then calculated according to implemented tests for dissolved carbon dioxide in the water ${ }^{21}$ and used ASTM method for measuring the elements and heavy metals in laboratory.

Data analysis methods of SPSS, ANOVA, Pearson correlation matrix: If the most important purpose is investigate for fundamental aspects that are not directly clear in data groups, the factor analysis method is appropriate ${ }^{9,22}$. The main purpose to apply factor analysis is to employ the calculated correlation matrix to recognize the minimum quantity of general parameters that the highest value give details or explanation for the correlation between the indicators (statistic). To realize a minor element arrangement that can be significantly explicated through the researcher, element rotation can be applied to recognize the majority probable aspects solution ${ }^{9,23}$. Data was analyzed using Statistical Package for Social Science (SPSS 19.0 IBM) to assess for significance differences contained by the physico-chemical factors with one-way analysis of variance (ANOVA), where significant values $(\mathrm{P}<0.05)$ were obtained, "A posteriori" Dunkan Multiple Range Test; afterwards was related to all of means pairs to find out the variance location. Pearason's rank correlation was applied to create relations between elements in the study area of Mashhad city ${ }^{11,24}$. Using UPGMA (Un-weighted Pair Grouping Method with Arithmeticmean) software as clustering method to obtain clear shape to show all measured traits in condition of research ${ }^{25}$ and Graph Pad Prism version 5 to obtain clear diagram related to SPSS parts.

Water metal index: With the purpose to evaluate the groundwater correlation in Mashhad considering metal pollution, the heavy elements concentrations were measured by the standard amount showed in Table- 5 .

The comparison of heavy elements concentrations with amount of maximum allowed concentration (MAC) standards, indicators for calculation the water pollution used. The index applied is named metal index (MI). The MI index at first was described by Tamasi and $\mathrm{Cini}^{26}$. This index can be stated as the following equation ${ }^{27}$ :

$$
\mathrm{MI}=\sum_{\mathrm{i}=1}^{\mathrm{N}} \frac{\mathrm{C}_{\mathrm{i}}}{(\mathrm{MAC})_{\mathrm{i}}}
$$

where $\mathrm{MI}$ is the metal index, $\mathrm{C}$ is per factor concentration in water, MAC is the maximum allowed concentration (for per element) and the subscript $i$ is the ith sample. The reported maximum metal concentration will compare with its relevant MAC significance. For, the worse water quality if the deter- 
mined factor concentration is higher than the relevant MAC importance (for axample MI > 1). Therefore the water cannot used based on index.

\section{RESULTS AND DISCUSSION}

Analysis of elements characteristic in ground water of Mashhad: Mean values \pm SE are from independent stations and values superscripted by different letters are significantly different by Duncan's multiple range tests $(\mathrm{p} \leq 0.01)$. The treatments were: [1] Control and [1]... [7] considered wells. Y axis shows dependent variable and $\mathrm{X}$ axis shows independent variables (water sampling stations).

Temperature (T): Ground water temperature in the studied area with the exception of the well no. 3 sample varies from about 19.8 to $21.8{ }^{\circ} \mathrm{C}$. The small differences observed are related to the static level of depth and also measurement time. As for well no. 3, the water temperature is equal to $25.2{ }^{\circ} \mathrm{C}$, despite the time difference related to the measuring and depth of water table, indicating the possibility that the water from this sample originated from another aquifer. Average temperature of all wells is between specified standard (20-30). There is no significant difference between wells except the well number 3 .

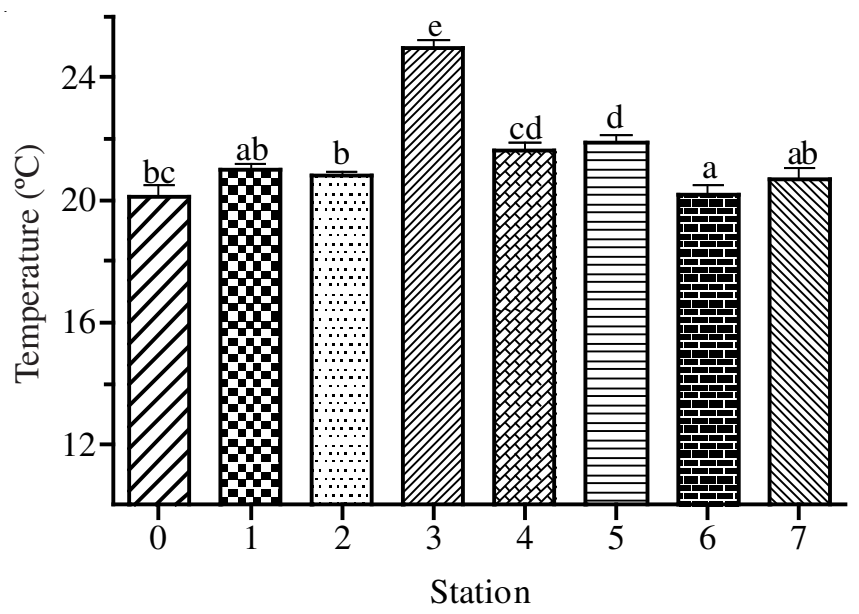

Fig. 2. Average amount of temperature between wells in Mashhad landfill

Electrical conductivity (EC): The amount of electrical conductivity in the samples changed from 505 to $2020 \mu \mathrm{S} /$ $\mathrm{cm}$. The samples of well no. 1 to 5 , respectively, are related to the deep available wells in the waterways downstream of the Mashhad landfill area. Their electrical conductivity from upstream to downstream waterways was shown to have increased, which is quite a natural phenomenon.

Channel water in travelling the distance from upstream to downstream, increases and adds to the ground water in the aquifer. The time the water stays in the aquifer allows for more material dissolution, causing the increase of soluble salts in the water, which has a direct relationship with the electrical conductivity of water.

For well no. 3, electrical conductivity average is 919.0092 $\mu \mathrm{S} / \mathrm{cm}$, as the water temperature of this well is different from the rest of the wells, probably to a different source of aquifer. Standard of electrical conductivity stated by WHO was 300 $\mu \mathrm{m} / \mathrm{cm}$. Electrical conductivity averages of all wells were higher than standard amount; specially for well no. 6 and 7 well were higher than the other stations. And the all wells had significantly difference but the well number 4 and 5 had the similar condition.

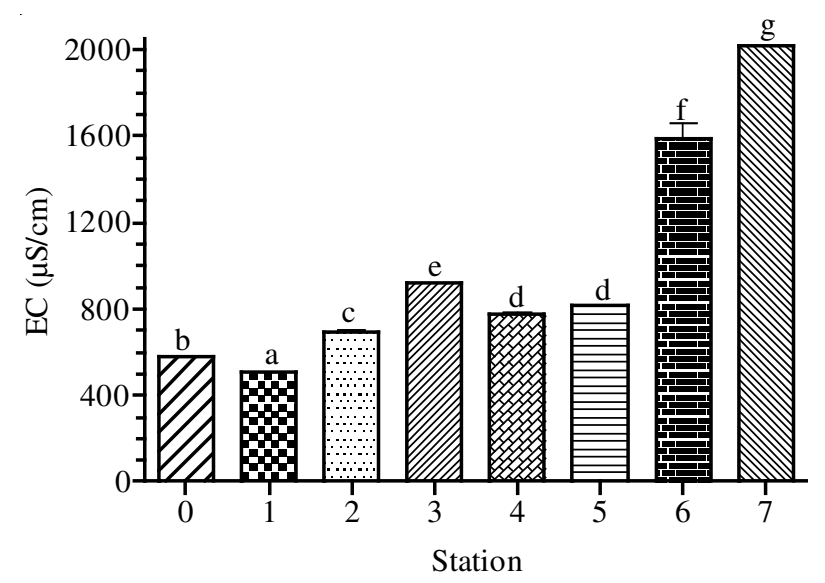

Fig. 3. Average amount of electrical conductivity between wells in Mashhad landfill

Hydrogen sulphide: Table-2 showed that in all cases the hydrogen sulphide gas in varying amounts indicates ground water pollution by waste. Samples of well no. 6 and 7 show highest concentrations of hydrogen sulphide gas (average 15.6503 and $14.5147 \mathrm{mg} / \mathrm{L}$ ) because of the wells being within the city and they expected impact from the adjacent sewage wells. The concentration of hydrogen sulphide gas in the rest of the wells, compared with samples of well no. 6 and 7 is considerably lower (because the wells are not affected by sewage wells). Sample from the well no. 1 showed higher hydrogen sulphide gas concentration than the others due probably to leachate leakage from the landfill, because this well is located adjacent to waterways that emanate from the landfill and in many cases inside that (the stream) leachate is outflow due to the waste; besides it is the well nearest the landfill. Fig. 4 shows the amount related to hydrogen sulphide (or sulphide) gas in different stations.

Amount of $\mathrm{H}_{2} \mathrm{~S}$ in well number 6 and 7 had significantly different with control well. The wells number of 2, 3, 4 and 5 had not significantly different $(\mathrm{P}<0.05)$ and the well number 1 had no significantly different in $95 \%$ level.

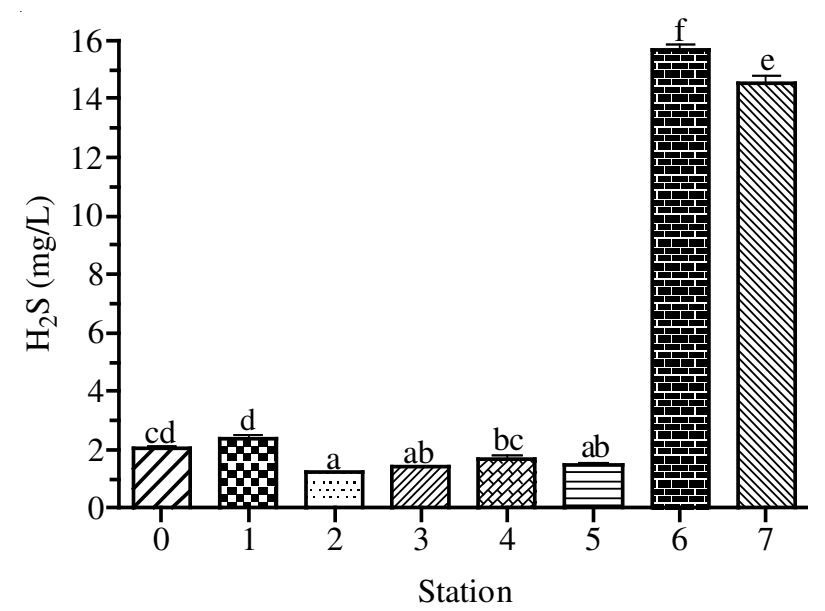

Fig. 4. Average amounts of $\mathrm{H}_{2} \mathrm{~S}$ between wells in Mashhad landfill 

SAMPLES IN MASHHAD JANUARY 2010 TO JANUARY 2011 (TWICE PER WEEK) BETWEEN 8 AM-12 NOON

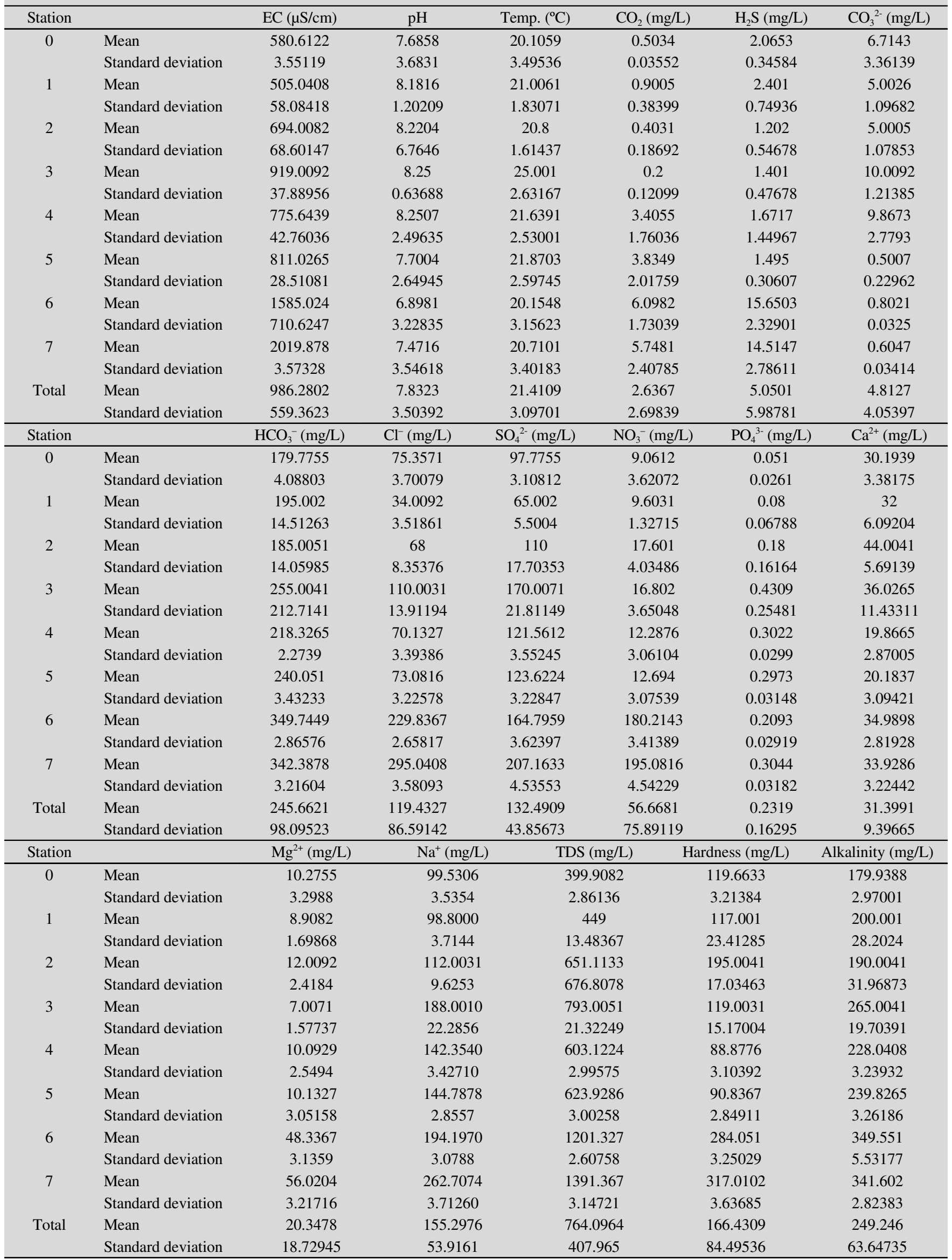


TABLE-3

STANDARD PARAMETER IDENTIFY

BY WHO FOR LEACHATE

\begin{tabular}{ll}
\hline \multicolumn{1}{c}{ Parameter } & \multicolumn{1}{c}{ WHO standards } \\
\hline $\mathrm{pH}$ & $6.5-9.2^{*}$ \\
Temperature $\left({ }^{\circ} \mathrm{C}\right)$ & $20-30^{\mathrm{a}}$ \\
Total dissolved solids $(\mathrm{mg} / \mathrm{L})$ & $500^{*}$ \\
Electrical conductivity $(\mu \mathrm{S} / \mathrm{cm})$ & $300^{+}$ \\
Total hardness & $50^{\mathrm{a}}$ \\
Sulphate & $200^{*}$ \\
Sodium & $200^{*}$ \\
$\mathrm{H}_{2} \mathrm{~S}$ & $\mathrm{NS}^{\mathrm{c}}$ \\
$\mathrm{HCO}_{3}^{-}, \mathrm{CO}_{2}$ & $80-160^{\mathrm{b}}$ \\
$\mathrm{Cl}^{-}$ & $400^{\mathrm{a}}$ \\
$\mathrm{SO}_{4}{ }^{2-}$ & $200^{*}$ \\
$\mathrm{Nitrate}\left(\mathrm{NO}_{3}{ }^{-}\right)$ & $40^{\mathrm{a}}$ \\
$\left.\mathrm{Phosphate} \mathrm{PO}_{4}{ }^{3-}\right)$ & $5^{\mathrm{a}}$ \\
$\mathrm{Mg}^{2+}$ & $50^{\mathrm{d}}$ \\
$\mathrm{Hardness}^{\mathrm{d}}$ & $300^{*}$ \\
Alkalinity as $\mathrm{CaCO}_{3}$ & $200-1000^{\mathrm{b}}$ \\
Calcium & $100^{\mathrm{d}}$ \\
\hline
\end{tabular}

*WHO 1997 (Ref. 28), ${ }^{+}$WHO 2003 (Ref. 29), ${ }^{a}$ WHO 2006 (Ref. 30), ${ }^{\mathrm{b}}$ (Ref. 31), ${ }^{\mathrm{c} N S}=$ Not Stated, ${ }^{\mathrm{d}} \mathrm{WHO} 2004$ (Ref. 32).

$\mathbf{C O}_{2}$ : The amount of dissolved carbon dioxide in water was highly variable in the study area, showing range from about 0.2 to $6.09 \mathrm{mg} / \mathrm{L}$. In samples 1 to 3 there is a low concentration of dissolved carbon dioxide because of the gas is consumed during the dissolution of calcium carbonate in the aquifer (ground water aquifer).

The samples well no. 4 to 7 are related to the wells located in areas an area that is under agriculture use. Here, because of relatively high carbon dioxide dissolved in the water of these wells, there is high carbon dioxide gas trapped in the soil (due to activities of microorganisms and plant roots) that cause rising concentrations of carbon dioxide in water from agricultural land that is returned to ground water from the aquifer. Wells of number 6 and 7 similar together and did not have significantly different between them and the wells number of 1, 2 and 3 had significant with control well. There is significant different between average amount of $\mathrm{CO}_{2}$ between the control well and well no. 1, 2 and 3 with the 4 and 5 and also 6 and 7 .

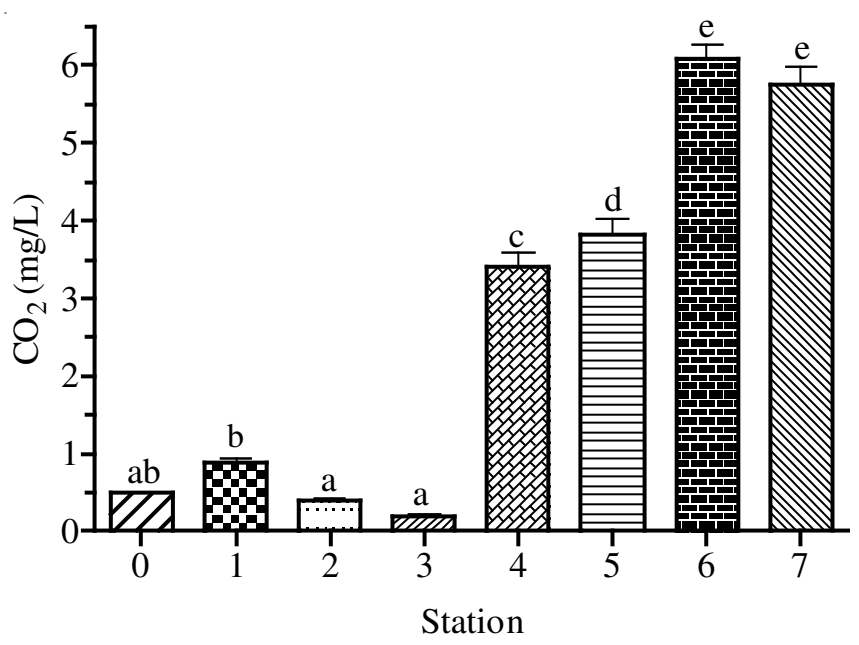

Fig. 5. Average amount of $\mathrm{CO}_{2}$ between wells in Mashhad landfill
Magnesium concentrations in the studied waters vary from 7 to $56.02 \mathrm{mg} / \mathrm{L}$ and in well number 6 the average of $\mathrm{Mg}$ computed 48.3367 . The magnesium standard concentration is measured by the amount of water sulphate, thus if the amount of sulphate is more than $250 \mathrm{mg} / \mathrm{L}$, the amount of magnesium must be a maximum of $50 \mathrm{mg} / \mathrm{L}$. The concentration of these cations based on the standard provided by the Institute of Standards \& Industrial Research of Iran (ISIRI) $56 \mathrm{mg} / \mathrm{L}$ and the maximum allowable amount of that concentration is 50 $\mathrm{mg} / \mathrm{L}$. The importance of magnesium concentration is its effect on water hardness, so that the hardness of water is determined according to the concentration of calcium and magnesium ions. Average amount of magnesium in wells number of 6 and 7 were more than the other wells. And amount of this parameter in wells number 1, 2, 3, 4, 5 and control were according to standard. There is no significant different between well number 4 and 5 with the control one also.

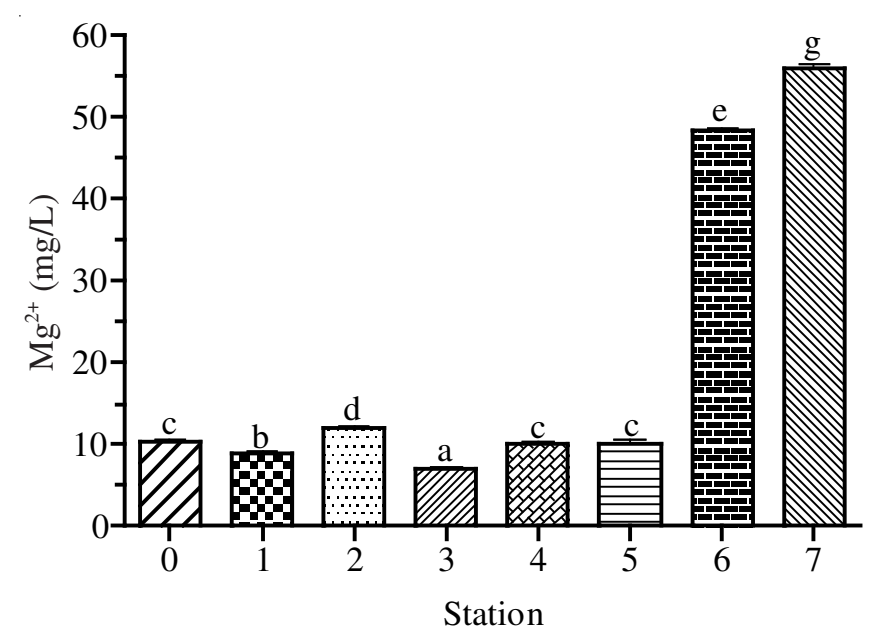

Fig. 6. Average amount of $\mathrm{Mg}^{2+}$ between wells in Mashhad landfill

As seen in Table-2, sodium values varied between 98.8 and $262.7 \mathrm{mg} / \mathrm{L}$. Sodium concentration in drinking water is usually less than $20 \mathrm{mg} / \mathrm{L}$ but in some areas it could exceed this amount. Currently, Health Guidelines have not provided for it but concentrations, above $200 \mathrm{mg} / \mathrm{L}$, may give it an unacceptable taste. Of course, according to European assembly instructions from year 1984, the equivalent concentration of $20 \mathrm{mg} / \mathrm{L}$ is offered as a guide and reduces the maximum concentration from 150 to $175 \mathrm{mg} / \mathrm{L}$. From the various samples 1, 2, 4 and 6 although these water resources are infected (by pollution) in terms of sodium. Meanwhile, it should be noted that the sodium is an effective component in agriculture. Sodium, because of two reasons is considered one of the most important parameters in irrigation water. (A) Impact on the physical properties of the soil and reducing the soil permeability and (B) another reason is the chemical impact on plants, high concentration causing the impairment, of the plant metabolism. The wells number 1 and control one have no significant different, number 4 and 5 also there is no significant different between them. Fig. 7 presents the related calculation of $\mathrm{Na}^{+}$in Mashhad area. Average amount of sodium in wells number 6 and 7 were significantly different with standard and control well in level of $95 \%$ according to statistical calculation. 


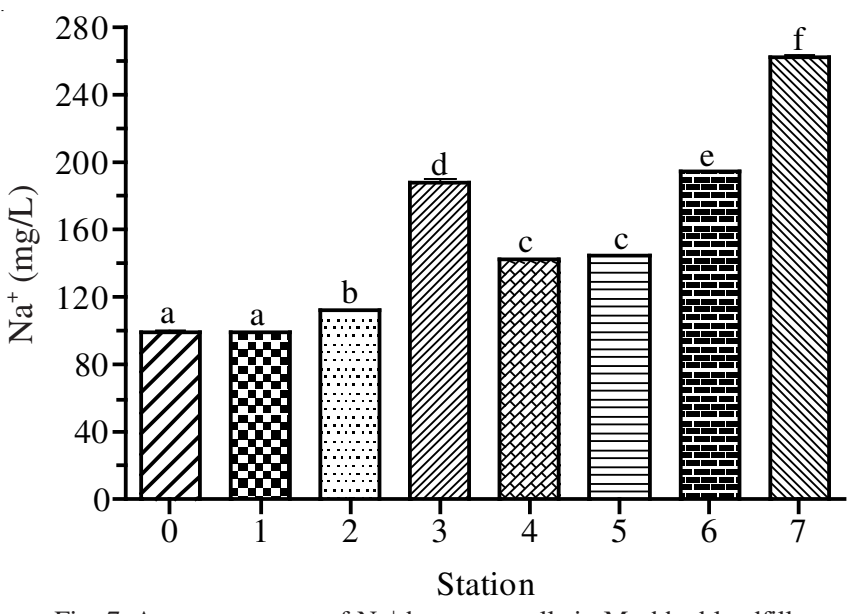

Fig. 7. Average amount of $\mathrm{Na}^{+}$between wells in Mashhad landfill

Calcium concentrations vary in the samples between 19.86 and $44.00 \mathrm{mg} / \mathrm{L}$ and according to the standards presented, there is no show of pollution (amount of standard is 100). Appropriate calcium range for drinking water varies between 70 and 200 (Ministry of Energy). Average amount of calcium did not have significantly different with standard. The amount of calcium in wells number 3, 6 and 7 were similar and wells number of 4 and 5 had the same condition each other.

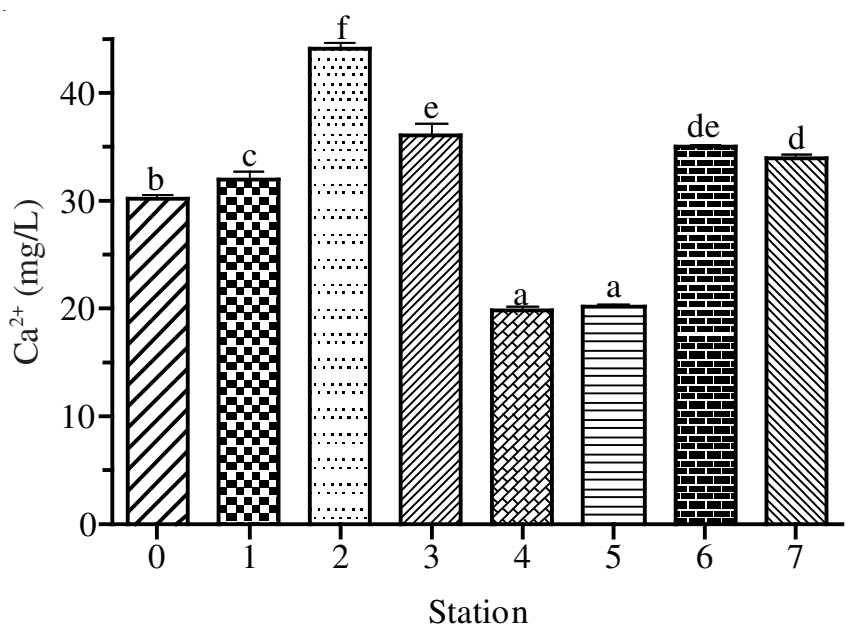

Fig. 8. Average amount of $\mathrm{Ca}^{2+}$ between wells in Mashhad landfill

Nitrate concentration varies between 9.06 and 195.08 $\mathrm{mg} / \mathrm{L}$ and nitrate is one of the important criteria for determining ground water pollution. Its high rate is harmful for humans and especially children. The concentration of $\mathrm{NO}_{3}{ }^{-}$in water should be less than $10 \mathrm{mg} / \mathrm{L}$ to be used as drinking water (Institute of Standards and Industrial Research). According to the Standards provided by the Institute of Standards and Industrial Research of Iran (ISIRI) in 2009, the maximum allowable amount of nitrate in drinking water is less than 45 $\mathrm{mg} / \mathrm{L}$ nitrate ions and international standard is 40. As the chart shows, except for the first Sample, the other samples are higher than the allowed nitrate standard for drinking water. Average amount of nitrate in wells number of 6 and 7 were higher than the stated standard by WHO but the other wells were less than amount of standard; the observed contamination is very worrying because this well is exactly near agricultural product. Wells number of 1 had same condition with control well, the wells number of 2 and 3 were the same condition and the wells number of 4 and 5 were similar together.

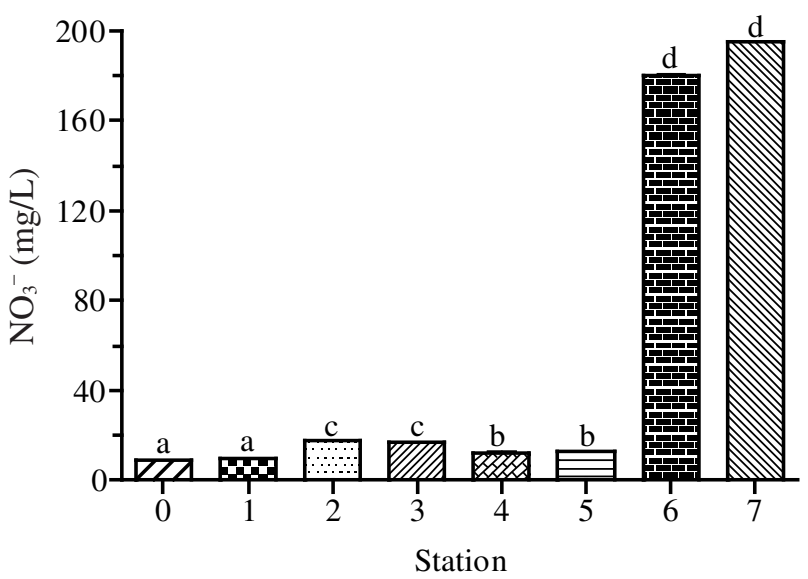

Fig. 9. Average amount of $\mathrm{NO}_{3}{ }^{-}$between wells in Mashhad landfill

According to Fig. 10 and Table-2, phosphate concentration average varies from 0.051 to $0.4309 \mathrm{mg} / \mathrm{L}$. Phosphates, through domestic sewage are compound a detergent containing phosphate, from the agricultural sewage that passes through the land with inorganic fertilizer or through the industrial waste water and contaminates the surface water. Ground water has small amounts of phosphate unless they have been infected for some reason. According to the standard stipulated by the Institute of Standards and Industrial Research of Iran (ISIRI) in 2009, the allowable concentration of phosphate is between 0.1 and $0.2 \mathrm{mg}$ and international standard is 5. Considering the source of $\mathrm{PO}_{4}{ }^{3-}$ is in the groundwater in terms of noncontaminated geological formation and in studied practice there is no phosphate formation, so it can be concluded that ecneteixe of phosphate in the samples is probably due to the presence of the landfill is located upstream of these wells. Another possible reason could be the use of phosphate fertilizers on farms in the vicinity of the wells from which the samples were drawn. Average amount of phosphate in all the wells were the same level of standard. The well number of 1 was similar the control well, the wells number 4, 5 and 7 were similar each other and wells number 2 and 6 had the similar condition.

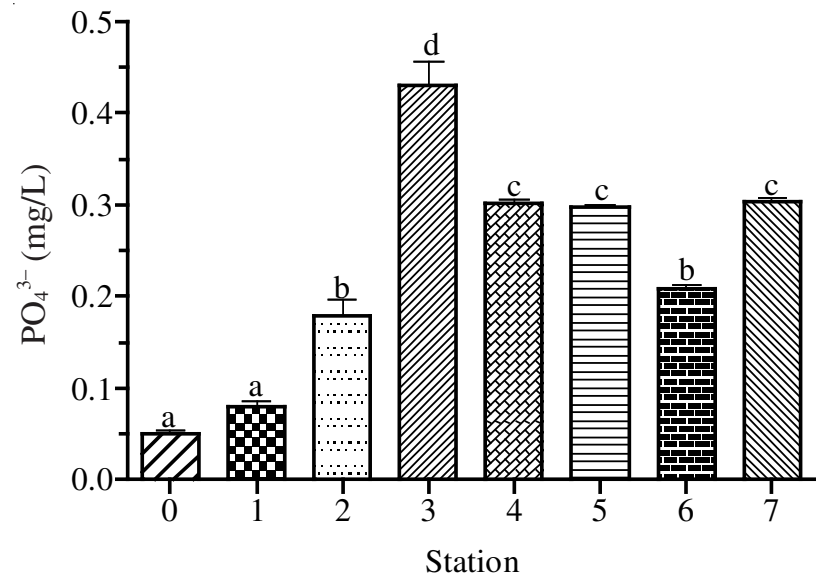

Fig. 10. Average amount of $\mathrm{PO}_{4}{ }^{3-}$ between wells in Mashhad landfill 
Concentrations of sulphate and chloride ions are not affected by geochemical processes, but can reduce the leachate effects on the affected water and also groundwater which has been affected by leachate. The standard extent ${ }^{33}$ of these two ions are $250 \mathrm{mg} / \mathrm{L}$ for chloride and for sulfate $500 \mathrm{mg} / \mathrm{L}$. Both of these ions are in accordance with the international standards. According to the standard provided by the Institute of Standards and Industrial Research of Iran (ISIRI) in 2009, sulphate (or sulfate) concentration could vary between 200 and $400 \mathrm{mg} / \mathrm{L}$ and chlorine concentration from 200 to 600 $\mathrm{mg} / \mathrm{L}$ (average 400). Leachate effects can be reduced largely by transferring leachate from landfill to septic wells and/or by building a concrete floor of the landfill during its construction and creating holes to serve as leachate collection pools. The well number of 7 had different significant with standard for sulphate and higher than amount of standard. Average amount of chloride in wells number 6 and 7 were different significant with the other wells but all of the wells were less than standard amount.

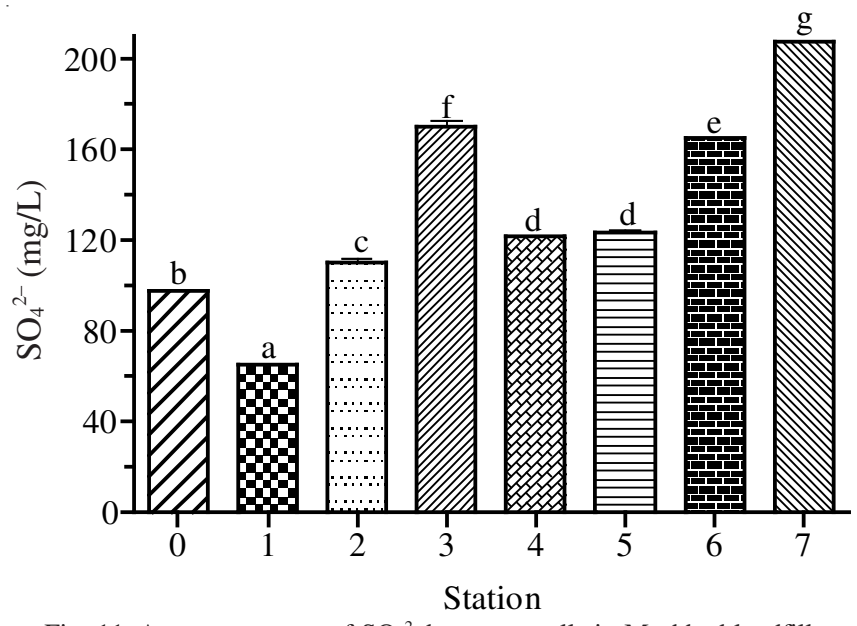

Fig. 11. Average amount of $\mathrm{SO}_{4}{ }^{2-}$ between wells in Mashhad landfill

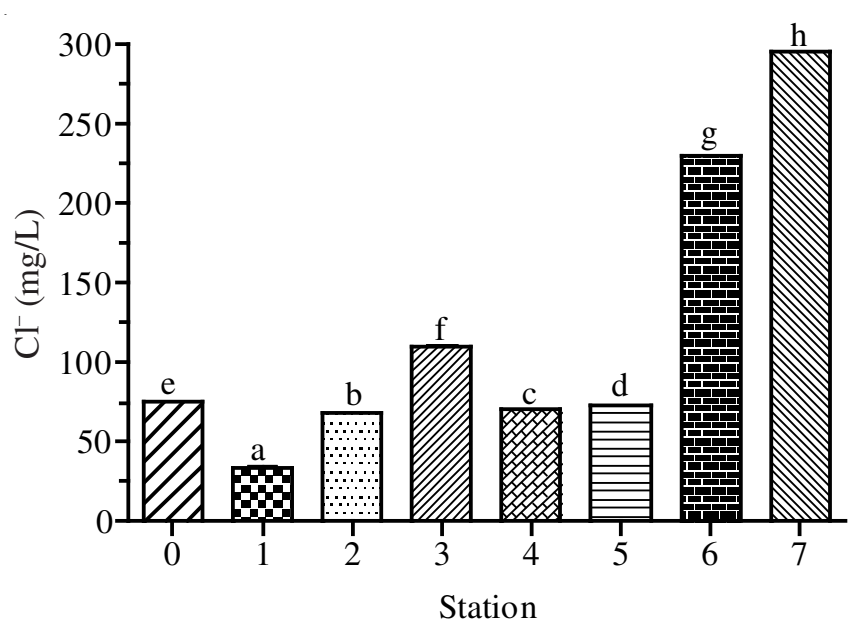

Fig. 12. Average amount of $\mathrm{Cl}^{-}$between wells in Mashhad landfill

The average amount of total dissolved solid (TDS) in control well was less than amount of standard, the well number 1 had the amount of standard (499.00) but all of the other wells were higher than the standard; especially wells number of 6 and 7.

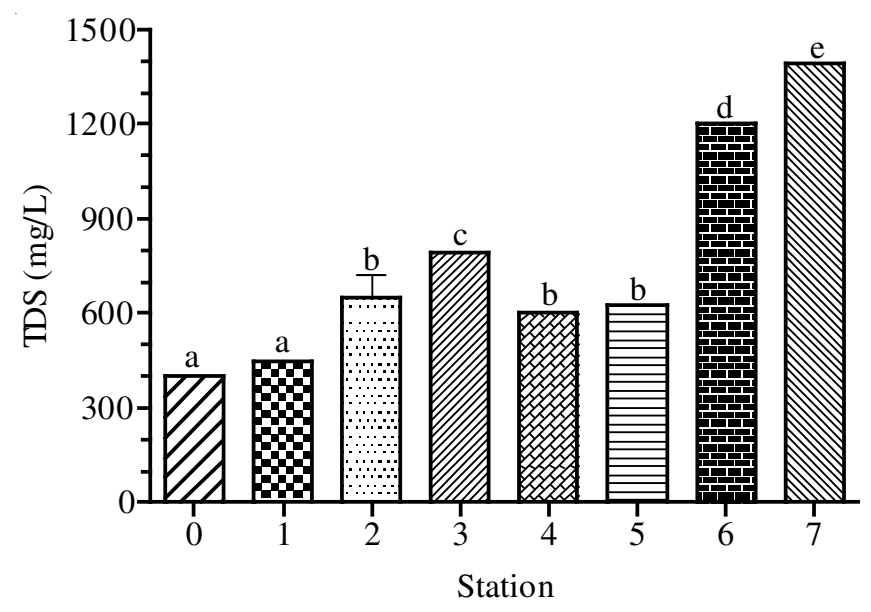

Fig. 13. Average amounts of TDS between wells in Mashhad landfill

Average amount of hardness in wells number of 6 and 7 were higher than standard amount. For hardness parameter the wells number of 4 and 5 had similar together and the wells number of 1 and 3 similar to the control one.

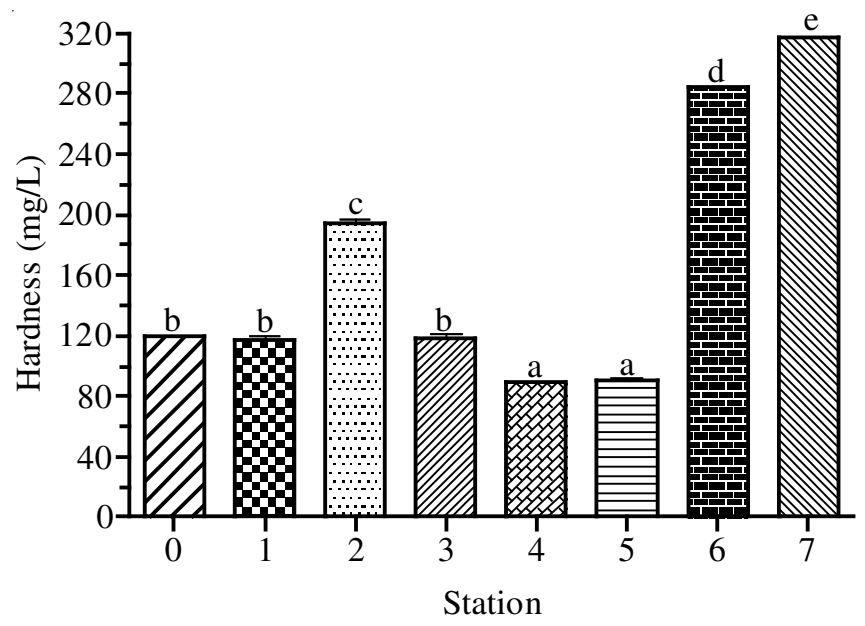

Fig. 14. Average amounts of TDS between wells in Mashhad landfill

Pearson correlation related to elements characteristic in ground water, Mashhad: The relationship between physicochemical parameters was examined using the Pearson's correlation. The correlation coefficient matrix for the water (wells) data in Mashhad is shown in Fig. 15. Strong correlations exist among pair elements of $\mathrm{Na}^{+}$and $\mathrm{H}_{2} \mathrm{~S}(\mathrm{r}=0.726), \mathrm{Cl}^{-}$and $\mathrm{H}_{2} \mathrm{~S}$ ( $\mathrm{r}=0.906), \mathrm{NO}_{3}{ }^{-}$and $\mathrm{H}_{2} \mathrm{~S}(\mathrm{r}=0.961), \mathrm{Mg}^{2+}$ and $\mathrm{H}_{2} \mathrm{~S}(\mathrm{r}=$ 0.946), $\mathrm{SO}_{4}{ }^{2-}$ and $\mathrm{Cl}^{-}(\mathrm{r}=0.853), \mathrm{NO}_{3}{ }^{-}$and $\mathrm{Cl}^{-}(\mathrm{r}=0.965)$, $\mathrm{Mg}^{2+}$ and $\mathrm{Cl}^{-}(\mathrm{r}=0.949), \mathrm{Na}^{+}$and $\mathrm{Cl}^{-}(\mathrm{r}=0.899), \mathrm{Na}^{+}$and $\mathrm{SO}_{4}{ }^{2-}(\mathrm{r}=0.928), \mathrm{Mg}^{2+}$ and $\mathrm{NO}_{3}{ }^{-}(\mathrm{r}=0.984), \mathrm{Na}^{+}$and $\mathrm{NO}_{3}{ }^{-}(\mathrm{r}$ $=0.808), \mathrm{Na}^{+}$and $\mathrm{Mg}^{2+}(\mathrm{r}=0.780)$ with $\mathrm{P}=0.01$; also $\mathrm{Mg}^{2+}$ and $\mathrm{PO}_{4}{ }^{3-}, \mathrm{Na}^{+}$and $\mathrm{Ca}^{2+}$ with $\mathrm{P}=0.05$. Fig. 15 shows that the poor to negative correlation exists between some of the parameters. Negative correlation coefficient of $\left(\mathrm{Na}^{+}, \mathrm{CO}_{3}{ }^{2-}\right)$, $\left(\mathrm{Mg}^{2+}, \mathrm{CO}_{3}{ }^{2-}\right),\left(\mathrm{NO}_{3}{ }^{-}, \mathrm{CO}_{3}{ }^{2-}\right),\left(\mathrm{SO}_{4}{ }^{2-}, \mathrm{CO}_{3}{ }^{2-}\right),\left(\mathrm{H}_{2} \mathrm{~S}, \mathrm{CO}_{3}{ }^{2-}\right)$ and $\left(\mathrm{Cl}^{-}, \mathrm{CO}_{3}{ }^{2-}\right)$ are also significant in $\mathrm{P}=0.01$ level. Temperature $\left({ }^{\circ} \mathrm{C}\right)$ exhibited a significant correlation with $\mathrm{CO}_{2}, \mathrm{H}_{2} \mathrm{~S}, \mathrm{CO}_{3}{ }^{2-}$, $\mathrm{Cl}^{-}, \mathrm{SO}_{4}{ }^{2-}, \mathrm{NO}_{3}{ }^{-}, \mathrm{PO}_{4}{ }^{3-}, \mathrm{Mg}^{2+}$ and $\mathrm{Na}^{+}$.

Conductivity is applied as a great quantity indicator for dissolved inorganic varieties or total concentration of ions $\mathrm{s}^{34}$. The EC correlated significantly with almost the elements. 


\begin{tabular}{|c|c|c|c|c|c|c|c|c|c|c|c|c|c|c|c|c|c|}
\hline & & & & & & & \multicolumn{3}{|c|}{ Pearson Correlation } & \multirow[b]{2}{*}{$\mathrm{NO}_{3}^{-}$} & \multirow[b]{2}{*}{$\mathrm{PO}_{3}^{3-}$} & \multirow[b]{2}{*}{$\mathrm{Ca}^{2+}$} & \multirow[b]{2}{*}{$\mathrm{Mg}^{2+}$} & \multirow[b]{2}{*}{$\mathrm{Na}^{+}$} & \multirow[b]{2}{*}{ TDS } & \multirow[b]{2}{*}{ Hardness } & \multirow[b]{2}{*}{ Alkalinity } \\
\hline & EC & $\mathrm{pH}$ & $\mathrm{T}\left({ }^{\circ} \mathrm{C}\right)$ & $\mathrm{CO}_{2}$ & $\mathrm{H}_{2} \mathrm{~S}$ & $\mathrm{CO}_{3}{ }^{2-}$ & $\mathrm{HCO}_{3}^{-}$ & $\mathrm{Cl}^{-}$ & $\mathrm{SO}_{4}^{2-}$ & & & & & & & & \\
\hline $\mathrm{EC} \mu \mathrm{S} / \mathrm{cm}$ & 1 & & & & & & & & & & & & & & & & \\
\hline $\mathrm{pH}$ & -0.064 & 1 & & & & & & & & & & & & & & & \\
\hline $\mathrm{CO}_{2}(\mathrm{mg} / \mathrm{L})$ & $.616^{* *}$ & $-.093 * *$ & $-.135 * *$ & 1 & & & & & & & & & & & & & \\
\hline $\mathrm{H}_{2} \mathrm{~S}(\mathrm{mg} / \mathrm{L})$ & $.785 * *$ & $-.093 * *$ & $-.181 * *$ & $.666 * *$ & 1 & & & & & & & & & & & & \\
\hline $\mathrm{CO}_{3}{ }^{2-}(\mathrm{mg} / \mathrm{L})$ & $-.461 * *$ & $.074 *$ & $.224 * *$ & $-.528 * *$ & $-.571 * *$ & 1 & & & & & & & & & & & \\
\hline $\mathrm{HCO}_{3}{ }^{-}(\mathrm{mg} / \mathrm{L})$ & $.541 * *$ & -0.07 & 0.023 & $.464 * *$ & $.567 * *$ & $-.329 * *$ & 1 & & & & & & & & & & \\
\hline $\mathrm{SO}_{4}{ }^{2-}(\mathrm{mg} / \mathrm{L})$ & $.770 * *$ & -0.045 & $.119 * *$ & $.504 * *$ & $.646 * *$ & $-.243 * *$ & $.516 * *$ & $.853 * *$ & 1 & & & & & & & & \\
\hline $\mathrm{NO}_{3}^{-}(\mathrm{mg} / \mathrm{L})$ & $.856 * *$ & $-.103 * *$ & $-.169 * *$ & $.697 * *$ & $.961 * *$ & $-.579 * *$ & $.593 * *$ & $.965 * *$ & $.730 * *$ & 1 & & & & & & & \\
\hline $\mathrm{PO}_{4}{ }^{3-}(\mathrm{mg} / \mathrm{L})$ & $.252 * *$ & 0.02 & $.290 * *$ & $.161 * *$ & 0.048 & $.100 * *$ & $.151 * *$ & $.222 * *$ & $.483 * *$ & $.112 * *$ & 1 & & & & & & \\
\hline $\mathrm{Ca}^{2+}(\mathrm{mg} / \mathrm{L})$ & $.132 * *$ & -0.012 & -0.037 & $-.197 * *$ & $.171 * *$ & -0.047 & 0.044 & $.196 * *$ & $.123 * *$ & $.204 * *$ & -0.065 & 1 & & & & & \\
\hline $\mathrm{Mg}^{2+}(\mathrm{mg} / \mathrm{L})$ & $.841 * *$ & $-.101 * *$ & $-.206 * *$ & $.696 * *$ & $.946 * *$ & $-.598 * *$ & $.564 * *$ & $.949 * *$ & $.698 * *$ & $.984 * *$ & $.077 *$ & $.187 * *$ & 1 & & & & \\
\hline $\mathrm{Na}^{+}(\mathrm{mg} / \mathrm{L})$ & $.827 * *$ & -0.059 & $.079 *$ & $.585 * *$ & $.726 * *$ & $-.333 * *$ & $.568 * *$ & $.899 * *$ & $.928 * *$ & $.808 * *$ & $.463 * *$ & $.090 *$ & $.780 * *$ & 1 & & & \\
\hline TDS (mg/L) & $.712 * *$ & -0.067 & -0.047 & $.532 * *$ & $.711 * *$ & $-.393 * *$ & $.495 * *$ & $.786 * *$ & $.717 * *$ & $.766 * *$ & $.277 * *$ & $.177 * *$ & $.745 * *$ & $.750 * *$ & 1 & & \\
\hline Hardness $(\mathrm{mg} / \mathrm{L})$ & $.777 * *$ & $-.090 *$ & $-.201 * *$ & $.528 * *$ & $.875 * *$ & $-.552 * *$ & $.495 * *$ & $.890 * *$ & $.639 * *$ & $.926 * *$ & 0.027 & $.434 * *$ & $.922 * *$ & $.693 * *$ & $.713 * *$ & 1 & \\
\hline \multicolumn{5}{|c|}{ *. Correlation is significant at the 0.05 level (2-tailed). } & & & & & & & & & & & & & \\
\hline
\end{tabular}

Fig. 15. Correlation matrix for different phisico-chemical parameters of groundwater samples, Mashhad

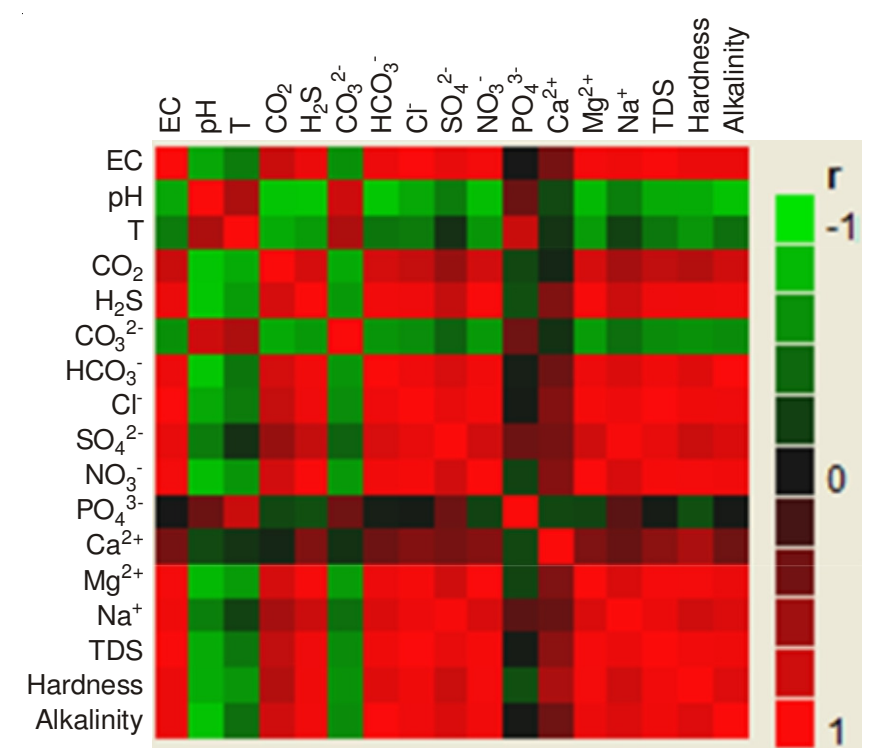

Fig. 16. Correlations between 17 characteristic for 7 wells. The strength and direction of the correlations among the different traits are indicated by the colour (red indicates positive correlations while green indicates negative correlations and the shading represents the strength of the correlation)

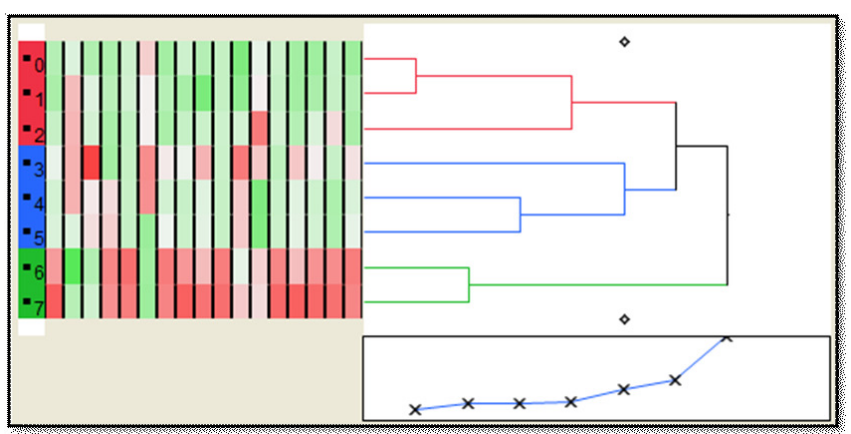

Fig. 17. Dendrogram generated by UPGMA clustering method of 7 stations. Of groundwater in Mashhad, based on all measured traits under leachate survey condition. Red colour refers to the high value of the studied traits while, green colour refers to the low value. The shading represents the strength of the trait, in which the bright colours have higher values than those shadows. The indicator box under the dendrogram demonstrates the number of accessions and the cutting point designates the number of clusters
Water metal index for Mashhad: The 1 value for MI is a warning threshold. The analyzed MI values are shown in a histogram (Figs. 6-33).

Findings of MI summarized in Table-5 and amount of them fluctuation between 0.080 and 2.56 . The wells number 1,2 and control were under threshold line (less than 1) and also wells number 4 and 5 had the similar condition and near the threshold amount; but the wells number 6 (2.077) and 7 (2.569) were higher than the threshold amount that because of near to old landfill site.

\begin{tabular}{ccccc}
\multicolumn{5}{c}{ TABLE-5 } \\
\multicolumn{5}{c}{ CALCULATED METAL INDEX (MI) FOR } \\
WATER SAMPLES IN MASHHAD \\
\hline Station & $\mathrm{Ca}^{2+}(\mathrm{mg} / \mathrm{L})$ & $\mathrm{Mg}^{2+}(\mathrm{mg} / \mathrm{L})$ & $\mathrm{Na}^{+}(\mathrm{mg} / \mathrm{L})$ \\
\hline MI 0 & 0.120776 & 0.205510 & 0.497653 & 0.823939 \\
MI 1 & 0.128000 & 0.178164 & 0.494000 & 0.800164 \\
MI 2 & 0.176016 & 0.240184 & 0.560016 & 0.976216 \\
MI 3 & 0.144106 & 0.140142 & 0.940005 & 1.224253 \\
MI 4 & 0.079466 & 0.201858 & 0.711770 & 0.993094 \\
MI 5 & 0.080735 & 0.202654 & 0.723939 & 1.007328 \\
MI 6 & 0.139959 & 0.966734 & 0.970985 & 2.077678 \\
MI 7 & 0.135714 & 1.120408 & 1.313537 & 2.569659 \\
\hline
\end{tabular}

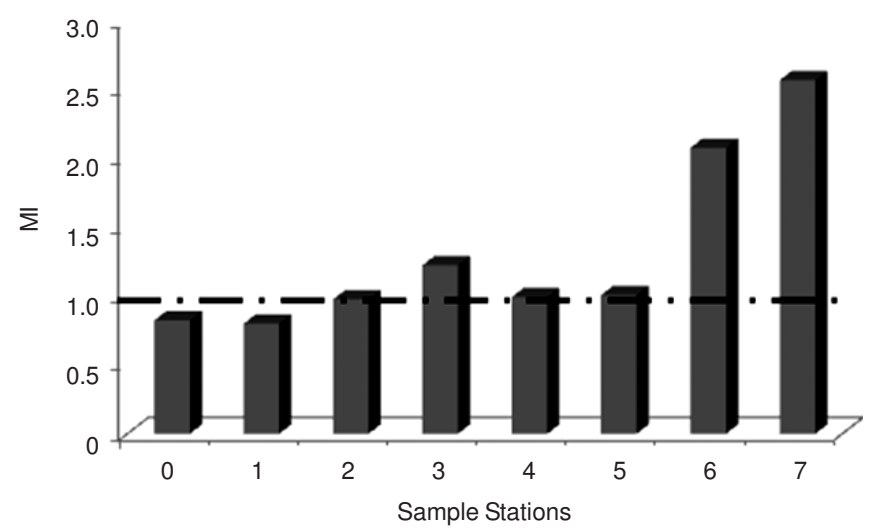

Fig. 18. Calculated metal index for water samples in the study area (20102011) 
TABLE-4

ANOVA WATER OF MASHHAD, JANUARY 2010 - JANUARY 2011

\begin{tabular}{|c|c|c|c|c|c|c|}
\hline & & Sum of Squares & $\mathrm{df}$ & Mean Square & $\mathrm{F}$ & Sig. \\
\hline \multirow[t]{3}{*}{$\mathrm{EC}(\mu \mathrm{S} / \mathrm{cm})$} & Between Groups & $1.948 \mathrm{E} 8$ & 7 & 27832065.281 & 430.529 & .000 \\
\hline & Within Groups & 50165460.156 & 776 & 64646.212 & & \\
\hline & Total & $2.450 \mathrm{E} 8$ & 783 & & & \\
\hline \multirow{3}{*}{$\mathrm{pH}$} & Between Groups & 163.066 & 7 & 23.295 & 1.913 & .065 \\
\hline & Within Groups & 9450.189 & 776 & 12.178 & & \\
\hline & Total & 9613.255 & 783 & & & \\
\hline \multirow[t]{3}{*}{ Temp $\left({ }^{\circ} \mathrm{C}\right)$} & Between Groups & 1711.180 & 7 & 244.454 & 32.712 & .000 \\
\hline & Within Groups & 5798.933 & 776 & 7.473 & & \\
\hline & Total & 7510.113 & 783 & & & \\
\hline \multirow[t]{3}{*}{$\mathrm{CO}_{2}(\mathrm{mg} / \mathrm{L})$} & Between Groups & 4133.753 & 7 & 590.536 & 292.348 & .000 \\
\hline & Within Groups & 1567.501 & 776 & 2.020 & & \\
\hline & Total & 5701.254 & 783 & & & \\
\hline \multirow[t]{3}{*}{$\mathrm{H}_{2} \mathrm{~S}(\mathrm{mg} / \mathrm{L})$} & Between Groups & 26464.405 & 7 & 3780.629 & 1823.161 & .000 \\
\hline & Within Groups & 1609.166 & 776 & 2.074 & & \\
\hline & Total & 28073.572 & 783 & & & \\
\hline \multirow{3}{*}{$\mathrm{CO}_{3}{ }^{2-}(\mathrm{mg} / \mathrm{L})$} & Between Groups & 10645.284 & 7 & 1520.755 & 530.849 & .000 \\
\hline & Within Groups & 2223.052 & 776 & 2.865 & & \\
\hline & Total & 12868.336 & 783 & & & \\
\hline \multirow{3}{*}{$\mathrm{HCO}_{3}^{-}(\mathrm{mg} / \mathrm{L})$} & Between Groups & 3100899.055 & 7 & 442985.579 & 77.534 & .000 \\
\hline & Within Groups & 4433655.130 & 776 & 5713.473 & & \\
\hline & Total & 7534554.185 & 783 & & & \\
\hline \multirow[t]{3}{*}{$\mathrm{Cl}^{-}(\mathrm{mg} / \mathrm{L})$} & Between Groups & 5838864.506 & 7 & 834123.501 & 20146.896 & .000 \\
\hline & Within Groups & 32128.018 & 776 & 41.402 & & \\
\hline & Total & 5870992.524 & 783 & & & \\
\hline \multirow[t]{3}{*}{$\mathrm{SO}_{4}{ }^{2-}(\mathrm{mg} / \mathrm{L})$} & Between Groups & 1420107.910 & 7 & 202872.559 & 1832.183 & .000 \\
\hline & Within Groups & 85924.355 & 776 & 110.727 & & \\
\hline & Total & 1506032.266 & 783 & & & \\
\hline \multirow[t]{3}{*}{$\mathrm{NO}_{3}^{-}(\mathrm{mg} / \mathrm{L})$} & Between Groups & 4500394.639 & 7 & 642913.520 & 53804.722 & .000 \\
\hline & Within Groups & 9272.437 & 776 & 11.949 & & \\
\hline & Total & 4509667.076 & 783 & & & \\
\hline \multirow{3}{*}{$\mathrm{PO}_{4}{ }^{3-}(\mathrm{mg} / \mathrm{L})$} & Between Groups & 11.082 & 7 & 1.583 & 126.534 & .000 \\
\hline & Within Groups & 9.709 & 776 & .013 & & \\
\hline & Total & 20.791 & 783 & & & \\
\hline \multirow[t]{3}{*}{$\mathrm{Ca}^{2+}(\mathrm{mg} / \mathrm{L})$} & Between Groups & 45098.580 & 7 & 6442.654 & 207.984 & .000 \\
\hline & Within Groups & 24037.937 & 776 & 30.977 & & \\
\hline & Total & 69136.516 & 783 & & & \\
\hline \multirow[t]{3}{*}{$\mathrm{Mg}^{2+}(\mathrm{mg} / \mathrm{L})$} & Between Groups & 269034.547 & 7 & 38433.507 & 5292.059 & .000 \\
\hline & Within Groups & 5635.690 & 776 & 7.262 & & \\
\hline & Total & 274670.237 & 783 & & & \\
\hline \multirow[t]{3}{*}{$\mathrm{Na}^{+}(\mathrm{mg} / \mathrm{L})$} & Between Groups & 2212242.477 & 7 & 316034.640 & 3837.968 & .000 \\
\hline & Within Groups & 63899.150 & 776 & 82.344 & & \\
\hline & Total & 2276141.627 & 783 & & & \\
\hline \multirow[t]{3}{*}{$\mathrm{TDS}(\mathrm{mg} / \mathrm{L})$} & Between Groups & 85820400.839 & 7 & 12260057.263 & 213.800 & .000 \\
\hline & Within Groups & 44498563.491 & 776 & 57343.510 & & \\
\hline & Total & 1.303E8 & 783 & & & \\
\hline \multirow[t]{3}{*}{ Hardness (mg/L) } & Between Groups & 5481529.115 & 7 & 783075.588 & 5591.690 & .000 \\
\hline & Within Groups & 108673.158 & 776 & 140.043 & & \\
\hline & Total & 5590202.273 & 783 & & & \\
\hline \multirow[t]{3}{*}{ Alkalinity (mg/L) } & Between Groups & 2951329.096 & 7 & 421618.442 & 1483.170 & .000 \\
\hline & Within Groups & 220592.332 & 776 & 284.268 & & \\
\hline & Total & 3171921.428 & 783 & & & \\
\hline
\end{tabular}

\section{Conclusion}

Improper techniques of management for municipal solid waste caused hazards in aspects of natural environment and public health. Low performance and absence of experimental studies before schematization and weak teamwork are some factors that have affected management of solid waste. The other challenges are related to deficient system policy implemention financial limitation ${ }^{35-38}$.

The characteristics of leachate produced during the processing and disposal of waste in Mashhad show that leachate produced from sources such as new waste, the compost heap and disposed waste have a very high degree of pollution. In that light, the concentration of measured parameters in the leachate produced in Mashhad is relatively higher compared to reported values in other countries. This issue is due to the different kinds of solid waste produced the in various countries, the separation degree of waste types, waste disposal and processing technologies and methods. All these variables differ from one country to another country. 
It is evident that downstream or groundwater of Mashhad landfill has been contaminated to some extent. The concentration of some elements was high when compared with standards of certain countries and WHO standards. There is no standard for soil in Iran and just for water in some area. According to Mashhad climatic and economical conditions, there are needs to set up standards and implement them in Mashhad.

\section{REFERENCES}

1. D. Kumar, B. Bhushan, N. Christ and B.J. Alappat, Effect of Leachate Recycling on Leachate Characteristics, Widener University and Journal of Solid Waste Management and Technology, The 20th International Conference on Solid Waste Technology and Management, Philadelphia, USA, 3-6 April (2005).

2. G.M. Masters, Introduction to Environmental Engineering, Upper Saddle River, Prentice Hall, NJ, edn. 2 (1998).

3. Y.-D. Guan, Y.-H. Du, H.-F. Ji, A.-C. Luo and B.-W. Zhao, Asian J. Chem., 24, 1185 (2012).

4. L.T. Orta, R.I. Monje, V.N. Rojas, G.J. Sánchez, G. Kiss and R.R. Cruz, Control Ambiental del Relleno Sanitario de Nuevo Laredo, Tamaulipas Final Report prepared for ICA-SETASA by the II-UNAM, Appendices I and II (1999) (in Spanish).

5. E.U. Johnbosco and A.O. Nnaji, Pak. J. Nutr., 10, 1053 (2011).

6. D.I. Olorunfemi, G. Jegede and C.C. Nnakwe, Continent. J. Environ. Sci., 5, 6 (2011).

7. I. Emmanuel, N. Joseph, E.-I. Kingsley, E.M. Egbebor and E. Lawrence, Nature Sci., 9, 46 (2011).

8. E.N. Ezekiel, E.N. Ogamba and J.F.N. Abowei, Asian J. Agric. Sci., 3, 200 (2011).

9. A.H. Charkhabi and M. Sakizadeh, Polish J. Environ. Stud., 15, 395 (2006).

10. T.O.T. Imoobe and P.I.O. Koye, J. Pure Appl. Sci., 4, 126 (2011).

11. J.D. Leckie, J.G. Pacey and C.P. Halvadakis, J. Environ. Eng., ASCE, 105(EE2), 337 (1979).

12. A. Kouzeli-Katsari, A. Bodogianni and D. Chritoulas, J. Environ. Eng. Div., 125, 950 (1999).

13. D. Kumar and B.J. Alappat, Clean Technol. Environ. Policy, 7, 190 (2005).

14. R. Rezaie, A. Mlaleki, M. Safari and A. Ghavami, Scient. J. Kurdistan Univ. Med. Sci., 15, 89 (2010).

15. G.R. Kassenga and S.E. Mbuligwe, J. Sustainable Develop. Africa, 10, 73 (2009).

16. I.O. Charles and I.A. Okoro, J. Appl. Sci. Environ. Sanitation, 7, 55 (2012).

17. C.K. Tay, R. Asmah and C.A. Biney, West African J. Appl. Ecol., 16, 75 (2009).
18. M. Ackah, O. Agyemang, A. K Anim, J. Osei, N.O. Bentil, L. Kpattah, E.T Gyamfi and J.E.K. Hanson, Assessment of Groundwater Quality for Drinking and Irrigation: The Case Study of Teiman-Oyarifa Community, Ga East Municipality, Ghana, Proceedings the International Academy of Ecology and Environmental Sciences, vol. 1(3-4), pp. 186-194 (2011).

19. R. Boghici, A Field Manual for Groundwater sampling (2003); http:// www.twdb.state.tx.us/groundwater/docs/UMs/UM-51.pdf.

20. W.S. Keys and L.M. MacCary, Application of Borehole Geophysics to Water-Resources Investigations: In Techniques of Water Resources Investigations, Book 2, chap. E1. Washington, DC: USGS (1971).

21. NNHS - Berg. Adapted from the NNHS Biology 611 Lab Manual pg. 65, BIO 611 Measurement of CO2 Produced by Humans (2012); http:// nnhsbergbio.pbworks.com/w/file/fetch/50172250/LAB_Measurement $\% 20$ of\%20CO2.pdf

22. J. Towned, Practical Statistics for Environmental and Biological Scientists, John Wiley \& Sons, New York, pp. 221-228 (2003).

23. S. Sharma, Applied Multivariate Techniques, John Wiley \& Sons, p. 144-181 (1996).

24. J.H. Zar, Biostatistical Analysis, Prentice Hall Inc., New Jersey, edn 2 (1984).

25. D. Talei, M.K. Yusop, M.A. Kadir, M.P. Abdullah and A. Valdiani, Aust. J. Crop Sci., 6,1059 (2012).

26. G. Tamasi and R. Cini, Sci. Total Environ., 327, 41 (2003).

27. H.H. Namaghi, G.H. Karami and S. Saadat, Environ. Monit. Assess., 174, 573 (2011).

28. World Health Organization (WHO), Guideline for Drinking Water Quality, Health Criteria and Other Supporting Information, Geneva, edn 2., Vol. 2, p. 9 (1997).

29. World Health Organization (WHO), Guideline for Drinking Water Quality, Geneva (WHO/SDE/WSH 03.04) (2003).

30. G. Tchobanoglous and F. Kreith, Handbook of Solid Waste Management, McGraw Hill, edn 2 (2002).

31. WHO, Guidelines for Drinking-water Quality, Geneva, edn. 3 (2004).

32. W.J. Deutsch, Groundwater Geochemistry: Fundamentals and Applications to Contamination, CRC Press (1997).

33. Iowa Department of Natural Resources Consultation Package, Water Quality Standards Review: Chloride, Sulfate and Total Dissolved Solids, 9th February (2009).

34. M. Banar, O. Aysun and K. Mine, Environ. Monitor. Assess., 121, 439 (2006).

35. O.N. Agdag and D.T. Sponza, Environ. Technol., 29, 183 (2008).

36. K. Refsgaard and K. Magnussen, J. Environ. Manage., 90, 760 (2009).

37. T. Eggen, M. Moeder and A. Arukwe, Sci. Total Enviorn., 408, 5147 (2010).

38. M. Farzadkia, S. Jorfi, H. Akbari and M. Ghasemi, Waste Manage. Res., 30, 106 (2012). 